\title{
Teacher-student Relationship and SNS-mediated Communication: Perceptions of both Role-players
}

\author{
Alona Forkosh-Baruch \\ Levinsky College of Education, Israel, and \\ School of Education, Tel Aviv University, Israel \\ alonabar@levisnky.ac.il
}

\section{Arnon Hershkovitz \\ School of Education, Tel Aviv \\ University, Israel}

arnonhe@tauex.tau.ac.il

\author{
Rebecca P. Ang \\ National Institute of Education, \\ Singapore
}

rebecca.ang@nie.edu.sg

\begin{abstract}
Material published as part of this publication, either on-line or in print, is copyrighted by the Informing Science Institute. Permission to make digital or paper copy of part or all of these works for personal or classroom use is granted without fee provided that the copies are not made or distributed for profit or commercial advantage AND that copies 1) bear this notice in full and 2) give the full citation on the first page. It is permissible to abstract these works so long as credit is given. To copy in all other cases or to republish or to post on a server or to redistribute to lists requires specific permission and payment of a fee. Contact Publisher@InformingScience.org to request redistribution permission.
\end{abstract}

Teacher-student relationships are vital for academic and social development of students, for teachers' professional and personal development, and for having a supportive learning environment. In the digital age, these relationships can extend beyond bricks and mortar and beyond school hours. Specifically, these relationships are extended today while teachers and students communicate via social networking sites (SNS). This paper characterizes differences between teachers $(\mathrm{N}=160)$ and students $(\mathrm{N}=587)$ who are willing to connect with their students/teachers via Facebook and those who do not wish to connect. The quantitative research reported here within is based on data collection of personal characteristics, attitudes towards Facebook, and perceptions of teacher-student relationship. Findings suggest differences in characteristics of the two groups (willing to connect vs. not willing to connect) within both populations (teachers and students). Also, in both populations, those who were willing to connect, compared to those who were not willing to connect, present more positive attitudes towards using Facebook for teaching/learning and are more opposed to a banning policy of student-teacher SNS-based communication. We also found that students who were willing to connect showed a greater degree of closeness with their teachers compared to those who were not willing to connect. This study may assist policymakers when setting up regulations regarding teacher-student communication via social networking sites.

Keywords: teacher-student relationship, social networking sites, SNS-mediated communication, Facebook

\section{Introduction}

The growing usage and popularity of social media applications has created new modes of communication and collaboration across the world and has

Editor: Janice Whatley

An earlier, shorter version of this paper was presented at the Chais conference 2015, in Raanana, Israel, and included in Y. Eshet-Alkalai, I. Blau, A. Caspi, N. Geri, Y. Kalman, \& V. Silber-Varod (Eds.), Proceedings of the 10th Chais Conference for the Study of Innovation and Learning Technologies 2015: Learning in the Technological Era. Raanana: The Open University of Israel. 
caused transformation and vast implications on all aspects of our lives (cf. Mioduser, Nachmias \& Forkosh-Baruch, 2008). Within the realm of social media, several fundamental issues arise, related to, e.g., self-exposure, intimacy, and self-expression (Amichai-Hamburger \& Vinitzky, 2010; Livingstone, 2008; Lowenthal, 2009; Marwick \& Boyd, 2010). The current knowledge era challenges society with a paradigm shift, setting demands for new tools and skills. Specifically, in the education field new pedagogical paradigms are encountered, e.g., new assumptions, concepts, and practices that shape our views of teachers' and students' roles, as well as the role of policy makers and educational systems at large. With regards to social media, teacher-student interactions should be carefully examined, as they dramatically affect communicating beyond boundaries of time and space.

Teachers, as well as educational systems at large, can benefit from these changes by facilitating contemporary educational paradigms (Abbott, 2005), allowing teachers to "[engage] in an authentic relationship with students where teachers know and respond with intelligence and compassion to students and their learning" (Rodgers \& Raider-Roth, 2006). This pattern of teacher-student communication challenges traditional paradigms in which communication is limited and based on traditional hierarchical teacher-student relationship and roles.

However, some changes are difficult to adopt by educational policymakers as they dramatically challenge long-established norms and traditions. The emergence of social networking sites, one of the prominent building stones of the Web 2.0 era, is perhaps the most salient example of the need to address unfamiliar educational scenarios. Social networking sites (SNS) are websites that enable their users to construct a public or semi-public profile and to build a personal inner network of connections (Boyd \& Ellison, 2007); SNS have become the most popular websites on the Internet and have been adopted by many teenagers worldwide (Boyd, 2008; Ellison \& Boyd, 2013; Lenhart, Madden, Macgill, \& Smith, 2007). SNS pedagogical usages have been extensively discussed from several points of view, e.g., the instruction point of view, learning possibilities, and challenges for formal and informal teaching and learning (e.g., Mazman \& Usluel, 2010; Veletsianos, Kimmons, \& French, 2013). However, there is still a lack of research regarding yet another angle related to the use of SNS in education, that is, the social and interpersonal aspects of SNSmediated communication between students and teachers. This is the unique angle we discuss in this paper, based on studies examining the relationships between students and teachers who are closely familiar with the SNS world. Mainly, we focus our attention on middle and high school students and teachers, as this population has special characteristics when it comes to SNS use and perceptions (cf. Boyd, 2014). Furthermore, while many studies have explored Facebook educational affordances in higher-education, studies in the context of secondary schools are relatively limited (cf. Hew, 2011).

SNS challenge the traditional dichotomy between students and teachers, as well as help re-invent student-teacher out-of-class communication in many ways. Hence, SNS carry educational promises, such as allowing available, enriched, and contextual student-teacher communication, or facilitating multi-channel learning experiences. Notwithstanding, SNS may also generate some undesired consequences, from being a waste of time to extreme cases of cyber-bullying, making this issue highly controversial in the public opinion. The moral and educational concerns involving SNS-based student-teacher communication reinforce the need for balancing opportunities and risks within policy (Livingstone \& Brake, 2009).

Some intriguing questions have been raised regarding student-teacher connections on SNS and their effect on student-teacher relationships in "real-life", and vice versa. Even the very term used in many SNS to describe connected users, "friends", may challenge traditional student-teacher hierarchy, as traditionally teachers are allowed some power over their students even when close relationship between the two are developed (Ang, 2005; Jaimeson \& Thomas, 1974; Steinfield, Ellison, \& Lampe, 2008; Vie, 2008). Albeit, closeness and friendship may be different in SNS 
compared to the real world (e.g., Subrahmanyam, Reich, Waechter, \& Espinoza, 2008; Van House, 2007).

This should be viewed in the light of an ever-changing role of teachers in the information era, as a result of blurring, even breakdown, of time and space boundaries (MacFarlane, 2001; Scardamalia \& Bereiter, 2006). This changes teaching paradigms, as well as the learning experience in its broader sense. However, although technology is a major factor in schools nowadays, teachers and students are still crucial players in this process (Elmore, 1996; Ertmer, 2005; Lambert, 2007). Teachers may change their role from "a sage on the stage" to "a guide on the side", that is, from a formalized, well-established format of traditional teaching and learning to a contemporary educational paradigm focusing on connecting to students, mentoring and assisting them (Abbott, 2005; Wong et al., 2006). SNS-based communication plays a major role in this change, extending the scope and setting in which teachers and students communicate. This may affect, in turn, mutual perceptions and beliefs (Mazer, Murphy, \& Simonds, 2009), thereby changing student-teacher relationships, followed by an even greater change in traditional hierarchical structures in schools.

For this reason, school authorities and policymakers have been pondering about their position regarding student-teacher SNS-based communication. Educational policymakers worldwide have adopted different educational approaches, often prohibiting teacher-student communication via SNS altogether. Public discussion on teacher-student communication via SNS reflects the complex nature of this issue, and overall demonstrates the difficulty in adapting novel tools in largescale systems and organizations. However, most policies are not based on empirical evidence.

The purpose of this paper is to present the emergence of SNS into students' and educators' lives and its effect on teacher-student relationships. We propose a quantitative view of this phenomenon via two empirical studies examining students' and teachers' perceptions of student-teacher communication via SNS, focusing on Facebook. These studies, presented here side by side, are a continuation of two exploratory, qualitative studies, in which students and teachers were interviewed in-depth regarding their beliefs about and usage of Facebook as a means for studentteacher communication (Forkosh-Baruch \& Hershkovitz, 2014).

\section{Research Questions}

Overall, we were interested in the differences (if there are any) between students and teachers

who are willing to connect to each other via social networking sites and those who are not willing to do so. We will shortly call them the willing-to-connect and the not-willing-to-connect groups (an overall of four groups, as students and teachers are studied separately). These groups will be defined in the Research Population section here below. Therefore, the research questions are the following:

1. What are the differences in personal characteristics between the willing-to-connect and the not-willing-to-connect students/teachers?

2. What are the differences in attitudes towards Facebook-use in education between the willing-to-connect and the not-willing-to-connect students/teachers?

3. What are the differences in teacher-student relationship between the willing-to-connect and the not-willing-to-connect students/teachers?

\section{Methodology}

The chosen methodology included a well-planned widespread procedure for collecting data from online questionnaires. From May until July 2013, we virally distributed a hyperlink of an online research questionnaire via social networking sites (mostly Facebook and Twitter), as well as via professional and personal mailing lists (the former includes, for example, mailing lists of centers 
for domain-specific teacher training). Our target population was teachers in lower and higher secondary schools. The questionnaire was built using Google Forms (see Instruments, below).

A similar process was replicated the next year with the student questionnaire, from which data was collected between December 2013 and April 2014. We virally distributed a hyperlink of an online research questionnaire via social networking sites (mostly Facebook), as well as via schools' and teachers' mailing lists.

\section{Research Variables}

\section{Teachers' Characteristics Included:}

- Age

- Gender

- Marital status [single, married, divorced, widowed]

- Teaching seniority [years]

- Experience on Facebook [years]

- Number of friends on Facebook

\section{Students' Characteristics Included:}

- Age

- Gender

- Grade [7-12]

- Experience on Facebook

- Number of friends on Facebook

\section{Attitudes towards Facebook-use in Education}

All participants were asked the following two questions:

1. Do you think Facebook can be used for educational purposes? [Yes/No]

2. There are countries/authorities prohibiting any teacher-student connection via Facebook. What is your standpoint on this policy? [a 1-5 Likert scale (completely disagree, tend to disagree, does not have an opinion, tend to agree, completely agree)]

\section{Teacher-Student Relationship}

All participants filled-out a section that included a questionnaire about teacher-student relationship; this was adapted to our study based on the Teacher-Student Relationship Inventory (TSRI) (Ang, 2005), see details in Instruments section below.

\section{Instruments}

We used two newly-developed versions of the Teacher-Student Relationship Inventory (TSRI), originally developed to measure teacher-student relationships, as reported by teachers, using 14 items graded on a 5-point Likert scale (completely disagree, tend to disagree, sometimes disagree and sometimes agree, tend to agree, completely agree) (Ang, 2005). For the purpose of the studies reported here, the questionnaire was translated to Hebrew and was adapted to measure:

- Teacher-class relationship, that is, the questionnaire was filled out by a teacher about a whole class. For example, the item "I enjoy having this student in my class" was translated to: "I enjoy teaching this class." (The full questionnaire appears in Appendix A.) We will refer to this new version as TCRI (Teacher-Class Relationship Inventory); 
- Student's perceptions of teacher-student relationship, that is, the questionnaire was filled by a student about one of their teachers. For example, the item "I enjoy having this student in my class" was translated to: "I think this teacher is enjoying having me in his/her class". (The full questionnaire appears in Appendix B.) We will refer to this new version as TSRI-S.

Both TCRI and TSRI-S were implemented as part of an online survey, using Google Forms. Within this form, teachers and students were asked about their current use of, and their connections with students/teachers (respectively), via Facebook. Following their answers, they were guided to choose a class or a teacher to which they will refer while replying TCRI or TSRI-S. For matter of simplicity, we will define the four groups of teachers (the student groups were defined similarly):

1. Teachers who have an active Facebook account and are connected to their current students. These are the connected teachers, and they were requested to fill in the questionnaire regarding a class they are currently teaching and to students from which they are currently connected on Facebook;

2. Teachers who have an active Facebook account, are not connected to their current students, but are interested in such a connection. These are the interested-in-connection teachers, and they were requested to fill in the questionnaire regarding a class they are currently teaching and to students to which they would like to be connected on Facebook;

3. Teachers who have an active Facebook account, are not connected to their current students, and are not interested in such a connection. These are the not-willing-to-connect teachers, and they were requested to fill in the questionnaire regarding an arbitrary class they currently teach.

4. Teachers who do not have an active Facebook account were also requested to fill in the questionnaire regarding an arbitrary class.

Eventually, we merged the first two groups - connected teachers and interested-in-connected teachers (groups 1 and 2 in the list above) - to form the willing-to-connect group to which we will refer from now on; pay attention that this group holds both teachers who are de-facto connected to their students and teachers who are not. This group will be compared to the not-willing-toconnect group (group 3 above). Very similarly, we define two groups of students: willing-toconnect and not-willing-to-connect. Group 4 (teachers and students who do not have Facebook accounts) were omitted from the current report.

\section{Population}

Altogether, 160 teachers and 587 students participated in this study (when omitting students and teachers who reported not having Facebook accounts). Teachers' age was 21-68 (M=47, $\mathrm{SD}=10.8)$, with $1-38$ years of teaching seniority $(\mathrm{M}=19, \mathrm{SD}=10.8)$, of whom 123 are females (77\%) and 37 are males (23\%). Students' age was 12-19 (M=14, SD=1.6), of whom 340 are female (58\%) and 247 are males (42\%). Participants were from all over Israel.

Distribution of the teachers and students to the willing-to-connect and not-willing-to-connect groups is presented in Table 1. 
Table 1. Distribution on the population into the main two groups of analysis

\begin{tabular}{|l|l|l|l|l|}
\hline \multirow{2}{*}{ Group } & \multicolumn{2}{|c|}{ Teachers } & \multicolumn{2}{c|}{ Students } \\
\cline { 2 - 5 } & \multicolumn{1}{|c|}{ N } & \multicolumn{2}{c|}{ N } & \multicolumn{2}{c|}{ N } \\
\hline $\begin{array}{l}\text { Willing-to- } \\
\text { connect }\end{array}$ & 109 & $68 \%$ & 191 & $33 \%$ \\
\hline $\begin{array}{l}\text { Not-willing-to- } \\
\text { connect }\end{array}$ & 51 & $32 \%$ & 396 & $67 \%$ \\
\hline Total & 160 & $100 \%$ & 587 & $100 \%$ \\
\hline
\end{tabular}

\section{Findings}

\section{Personal Characteristics}

\section{Teachers' personal characteristics}

Using t-test, we compared means of the variables describing personal teacher characteristics, i.e., age, teaching seniority, experience on Facebook and number of Facebook-friends, between the two groups. Results show that on average, the willing-to-connect teachers are significantly younger than the not-willing-to-connect teachers; the average of the former is $44.8(\mathrm{SD}=11.0)$ and of the latter $49.6(9.6), \mathrm{t}(157)=2.6$, at $\mathrm{p}<0.01$, with a medium effect size (Cohen's $\mathrm{d}=0.42$ ). As for teaching seniority, the mean over the willing-to-connect teachers $(17.0, \mathrm{SD}=10.9)$ is significantly smaller than the mean over the not-willing-to-connect teachers $(21.6, \mathrm{SD}=10.1), \mathrm{t}(158)=2.5$, at $\mathrm{p}<0.05$, with a medium effect size $(\mathrm{d}=0.40)$.

In addition, findings show that on average, willing-to-connect teachers have significantly longer Facebook-usage experience than their not-willing-to-connect colleagues, while the mean of the former is $4.0(\mathrm{SD}=1.8)$, the mean of the latter is $3.3(\mathrm{SD}=1.5)$, with $\mathrm{t}(158)=2.3$, at $\mathrm{p}<0.05$, a medium effect size $(\mathrm{d}=0.37)$. The number of Facebook friends was not found to be significantly different between the two groups. Results are summarized in Table 2.

Differences in gender and marital status were tested using $\chi^{2}$; no significant differences were found between the two groups in gender, $\chi^{2}(1)=1.3$, at $p=0.26$, nor in marital status, $\chi^{2}(3)=3.3$, at $\mathrm{p}=0.35$.

\section{Students' personal characteristics}

Next, we compared means of the variables describing personal student characteristics, i.e., age, experience on Facebook and number of Facebook-friends, between the two groups (using t-test). Results show that on average, the willing-to-connect students are significantly older than the notwilling-to-connect students; the average age of the former is $14.5(\mathrm{SD}=1.8)$ and of the latter 13.7 (1.4), $\mathrm{t}(309.8)=5.4$, at $\mathrm{p}<0.01$ (As Levene's test for equal variances was significant, equal variances were not assumed), with a high effect size (Cohen's $d=0.61$ ).

Number of Facebook friends was found to be significantly different between the two groups. The willing-to-connect students had 609 Facebook-friends on average ( $\mathrm{SD}=618)$, while the notwilling-to-connect students had only $505(\mathrm{SD}=411)$, with $\mathrm{t}(259.7)=2.1$ (As Levene's test for equal variances was significant, equal variances were not assumed), at $\mathrm{p}<0.01$, with a small effect size $(d=0.26)$. No significant difference was found between the two groups in Facebook-usage experience. Results are summarized in Table 2. 
Difference in gender between two groups was tested using $\chi^{2}$ and was found significant; There are relatively more boys in the willing-to-connect group (49\%, 94 of 191) than in the not-willingto-connect group $(39 \%, 153$ of 396$)$, with $\chi^{2}(1)=5.9$, at $p<0.05$.

Table 2. Mean (SD) for the variables describing personal characteristics of teachers and students

\begin{tabular}{|c|c|c|c|c|c|c|}
\hline \multirow[t]{2}{*}{ Variable } & \multicolumn{3}{|c|}{ Teachers } & \multicolumn{3}{|c|}{ Students } \\
\hline & $\begin{array}{c}\text { willing- } \\
\text { to- } \\
\text { connect }\end{array}$ & $\begin{array}{c}\text { not- } \\
\text { willing- } \\
\text { to- } \\
\text { connect }\end{array}$ & $\mathbf{T}$ & $\begin{array}{l}\text { willing- } \\
\text { to- } \\
\text { connect }\end{array}$ & $\begin{array}{c}\text { not- } \\
\text { willing- } \\
\text { to- } \\
\text { connect }\end{array}$ & $\mathbf{t}$ \\
\hline Age & $\begin{array}{c}44.8 \\
(11.0) \\
\mathrm{N}=109\end{array}$ & $\begin{array}{l}49.6 \\
(9.6) \\
\mathrm{N}=50\end{array}$ & $\begin{array}{c}2.6^{* *} \\
d f=157\end{array}$ & $\begin{array}{c}14.5(1.8) \\
\mathrm{N}=191\end{array}$ & $\begin{array}{c}13.7(1.4) \\
\mathrm{N}=395\end{array}$ & $\begin{array}{c}5.4^{* *} \\
\mathrm{df}=309.8^{1}\end{array}$ \\
\hline $\begin{array}{l}\text { Teaching } \\
\text { seniority } \\
\text { [years] }\end{array}$ & $\begin{array}{c}17.0 \\
(10.9) \\
\mathrm{N}=109\end{array}$ & $\begin{array}{c}21.6 \\
(10.1) \\
\mathrm{N}=51\end{array}$ & $\begin{array}{c}2.5^{*} \\
\mathrm{df}=158\end{array}$ & & & \\
\hline $\begin{array}{l}\text { Facebook- } \\
\text { use expe- } \\
\text { rience } \\
\text { (years) }\end{array}$ & $\begin{array}{l}4.0(1.8) \\
\mathrm{N}=109\end{array}$ & $\begin{array}{c}3.3(1.5) \\
\mathrm{N}=51\end{array}$ & $\begin{array}{c}2.3^{*} \\
\mathrm{df}=158\end{array}$ & $\begin{array}{l}4.2(1.5) \\
N=189\end{array}$ & $\begin{array}{l}4.0(1.5) \\
\mathrm{N}=389\end{array}$ & $\begin{array}{c}1.7 \\
\mathrm{df}=576\end{array}$ \\
\hline $\begin{array}{l}\text { Number } \\
\text { of Face- } \\
\text { book- } \\
\text { friends }\end{array}$ & $\begin{array}{c}273.5 \\
(391.4) \\
N=109\end{array}$ & $\begin{array}{c}179.4 \\
(362.9) \\
\mathrm{N}=51\end{array}$ & $\begin{array}{c}1.4 \\
\mathrm{df}=158\end{array}$ & $\begin{array}{c}609(618) \\
N=181\end{array}$ & $\begin{array}{c}505(411) \\
N=373\end{array}$ & $\begin{array}{c}2.1^{* *} \\
\mathrm{df}=259.7^{1}\end{array}$ \\
\hline
\end{tabular}

${ }^{1}$ Levene's test for equal variances was significant, hence equal variances were not assumed

\section{Attitudes towards Using Facebook in Education}

\section{Teachers' attitudes towards using Facebook in education}

The distribution of the nominal variables was compared using a $\chi^{2}$ test. The two variables show significant difference between the two teacher groups. Among the willing-to-connect teachers, 94\% (102 of 109) asserted that Facebook can be used for teaching, as opposed to only $62 \%$ (31 out of 51) among the not-willing-to-connect teachers, $\chi^{2}(1)=26.6, p<0.01$. As for teachers' attitude towards the banning regulation, $87 \%$ (95 of 107) of the willing-to-connect teachers disagreed or tended to disagree with this policy, as opposed to only $35 \%$ (18 out of 50) among the notwilling-to-connect teachers, $\chi^{2}(1)=47.1, p<0.01$. Only 3 teachers $(3 \%)$ responded that they did not have an opinion about the banning policy (they were omitted in this analysis).

Summarizing the comparison of the willing-to-connect and the not-willing-to-connect teachers, we conclude that the former are younger, less experienced in teaching, and more experienced on Facebook than the latter. Additionally, the willing-to-connect teachers tend to believe that Facebook can be used for teaching/learning and that it should not be banned for teacher-student communication in much higher numbers than the not-willing-to-connect teachers. 


\section{Students' attitudes towards using Facebook in education}

The distribution of the nominal variables was compared using a $\chi^{2}$ test. The two variables show significant difference between the two student groups. Among the willing-to-connect students, $70 \%$ (133 of 191) asserted that Facebook can be used for learning, as opposed to only 47\% (185 of 396) among the not-willing-to-connect students, $\chi^{2}(1)=27.3, p<0.01$. As for students' attitude towards the banning regulation, $66 \%$ (95 of 143) of the willing-to-connect students disagree or tend to disagree with this policy, as opposed to only $25 \%$ (70 of 285) among the not-willing-toconnect students, $\chi^{2}(1)=70.5, p<0.01$. More than a quarter of all students $(159$ of $587,27 \%)$ responded that they did not have an opinion about the banning policy and were not counted in this analysis.

Additionally, gender was found to be significantly different between the two student groups. Of the willing-to-connect students, $49 \%$ were males (94 of 191), compared to $39 \%$ males in the notwilling-to-connect group (153 of 396), with $\chi^{2}(1)=5.9$, at $\mathrm{p}<0.05$.

Summarizing the comparison of the willing-to-connect and the not-willing-to-connect students, we conclude that the former are older and have more Facebook-friends than the latter and that the former group has a higher rate of males than the latter. Additionally, the willing-to-connect students tend to believe that Facebook can be used for learning and that it should not be banned for teacher-student communication in higher numbers than the not-willing-to-connect students.

\section{Perceptions of Teacher-Student Relationships}

\section{Teachers' perception of teacher-student relationship}

The original TSRI was validated as having three axes: Satisfaction (items 1, 3, 5, 13, 14), Instrumental Help (items 2, 6, 9, 10, 12) and Conflict $(4,7,8,11)$. As we have translated and adapted it, we tested the new TCRI for inter-consistency, using Cronbach's $\alpha$, based on these three axes. Results are promising, with $\alpha=0.83$ for satisfaction and instrumental help and $\alpha=0.67$ for conflict.

There were no significant differences in any of TCRI axes between the two groups of teachers (willing-to-connect and not-willing-to-connect). Findings are summarized in Table 3.

\section{Students' Perception of Teacher-Student Relationship}

As detailed above, we needed to check TSRI-S for inter-consistency, due to the translation and adaptation of the original TSRI. Cronbach's $\alpha$ values are very good, with $\alpha=0.88$ for satisfaction and conflict and $\alpha=0.86$ for instrumental help.

Comparing TSRI-S axes between the wiling-to-connect and the not-willing-to-connect students, we find significant differences in two axes. Satisfaction mean was higher in the willing-toconnect group (3.9, $\mathrm{SD}=1.0)$ than in the not-willing-to-connect group $(3.7, \mathrm{SD}=1.1)$, with $\mathrm{t}(421.5)=3.0$, at $\mathrm{p}<0.01$ (As Levene's test for equal variances was significant, equal variances were not assumed), with a medium effect size (0.3). Instrumental mean help was higher in the willing-to-connect group (3.1, SD=1.1) than in the not-willing-to-connect group (2.6, $\mathrm{SD}=1.1)$, with $\mathrm{t}(585)=5.2$, at $\mathrm{p}<0.01$, with a medium effect size (0.43). No significant difference was found between the two groups of students in the conflict axe. Findings are summarized in Table 3. 
Table 3. Mean (SD) for the TCRI axes teachers and students

\begin{tabular}{|c|c|c|c|c|c|c|}
\hline \multirow[t]{2}{*}{ Variable } & \multicolumn{3}{|c|}{ Teachers } & \multicolumn{3}{|c|}{ Students } \\
\hline & $\begin{array}{c}\text { willing- } \\
\text { to- } \\
\text { connect } \\
(N=109)\end{array}$ & $\begin{array}{c}\text { not- } \\
\text { willing- } \\
\text { to- } \\
\text { connect } \\
(\mathrm{N}=51)\end{array}$ & $t$ & $\begin{array}{c}\text { willing- } \\
\text { to- } \\
\text { connect } \\
(\mathrm{N}=191)\end{array}$ & $\begin{array}{c}\text { not- } \\
\text { willing- } \\
\text { to- } \\
\text { connect } \\
(\mathrm{N}=396)\end{array}$ & t \\
\hline Satisfaction & $4.4(0.6)$ & $4.4(0.6)$ & $\begin{array}{c}0.3 \\
(\mathrm{df}=158)\end{array}$ & $3.9(1.0)$ & $3.7(1.1)$ & $\begin{array}{c}3.0^{* *} \\
(\mathrm{df}=421.5)^{1}\end{array}$ \\
\hline $\begin{array}{l}\text { Instrumental } \\
\text { Help }\end{array}$ & $3.7(0.8)$ & $3.8(0.7)$ & $\begin{array}{c}0.5 \\
(\mathrm{df}=158)\end{array}$ & $3.1(1.1)$ & $2.6(1.1)$ & $\begin{array}{c}2.5^{* *} \\
(\mathrm{df}=585)\end{array}$ \\
\hline Conflict & $1.5(0.6)$ & $1.4(0.5)$ & $\begin{array}{c}1.1 \\
(\mathrm{df}=132.3)^{1}\end{array}$ & $1.6(0.9)$ & $1.7(1.0)$ & 1.0 \\
\hline
\end{tabular}

${ }^{1}$ Levene's test for equal variances was significant, hence equal variances were not assumed

\section{Discussion}

In this research, we have studied the associations between teacher-student relationships and teachers' and students' beliefs about, and actual usage of, SNS-mediated communication, focusing on Facebook. Specifically, we have compared two sub-populations of teachers and students: Those who are willing to connect as Facebook-friends to the "other side" (whether they are actually connected to them or not) and those who are not willing to connect. As Facebook-friendship requires both sides' agreement to take place, this distinction is critical as it relies on the participants' motivation for such a connection. Therefore, and in order to evoke the participants to consider all the pros and cons of connections via Facebook, we have explicitly focused on Facebookfriendship, the strongest type of connection via this SNS. Of course, other types of teacherstudent communication are feasible on Facebook, the most common of which is communication via Groups (Asterhan \& Rosenberg, 2015). However, we believe that in order to explore the full range of relationships, Facebook-friendship is a better choice to explore, as it might break the traditional barriers between "academic" and "social" and between "work" and "after school". Some countries prohibit such a connection (as is the case in Israel, where the current study took place), in which case the willing to de-facto connect might indeed imply a greater motivation to strengthen the relationship between one another. Furthermore, as previous studies have shown, students do not perceive Facebook as a place for teaching/learning and prefer to keep it for their own place to socialize with their peers (Brandtzæg, Heim, \& Kaare, 2010; Durrant, Frohlich, Sellen, \& Uzzell, 2011; Halverson, 2014; Hershkovitz \& Forkosh-Baruch, 2013; Livingstone, 2008), which makes these students who are willing to be Facebook-friends with their teachers interesting to examine. The importance of this study is also strengthened in the light of the fact that only a few studies in recent years have been exploring teacher-student SNS-mediated communication in elementary or secondary education, and there might be a big difference between teenagers and young adults with regards to the effects of SNS use on school-related measures (Koles \& Nagy, 2012). Hew (2011), in his literature review of 539 articles discussing Facebook use in schools, did not find a single study about this population (all were referring to college and university population); however in recent years the study of secondary school populations has been emerging (e.g., Asterhan \& Rosenberg, 2015; Blonder \& Rap, in press; Greenhow, 2011; Halverson, 2014; Ranieri, Manca, \& Fini, 2012). 
When examining the personal characteristics of teachers and students who are willing to be Facebook-friends with each other (i.e., teachers with students and students with teachers), our findings suggest that both teachers and students on these groups have richer activity on Facebook - more friends for students, more Facebook-use experience for teachers - than those who are not willing to connect. Interestingly, the willing-to-connect teachers are younger than the not-willing-toconnect group, and the willing-to-connect students are older than those who are not willing to connect; that is, the willing-to-connect students and teachers are closer in age than the notwilling-to-connect ones. This is in line with previous studies which have found that as the age difference between teachers and students increases, students' and teachers' perceptions of the value of their relationship with one another decreases (Ang, Chon, Huan, Quek, \& Yeo, 2008; Saft \& Pianta, 2001; Yeo, Chong, Huan, \& Quek, 2008). Therefore, it might be that teachers and students who are traditionally known to be in good relationships with each other are willing to use Facebook as yet another platform to strengthen their relationships.

An interesting difference between the willing-to-connect and the not-willing-to-connect student groups is in gender; among the former, there are relatively more boys than among the latter. As Barker (2009) found, male adolescents are more likely to use SNS-based communication for social compensation and social identity. Our findings might mirror Barker's notion of social compensation to the context of student-teacher relationship, as it is known that male students have more conflictual relationships with teachers than female students do, and that female teachers have closer relationships with female students than with male students (e.g., Quaglia, Gastaldi, Prino, Pasta, \& Longobardi, 2013; Split, Koomen, \& Jak, 2012). Therefore, male students might find themselves inferior to their female peers regarding the relationships with their teachers (who are mostly female), hence the possible need for online compensation.

As our findings suggest, there is a positive association between students' perceptions of studentteacher relationships in general and the willingness of the two sides to connect on Facebook. The group of willing-to-connect students is characterized with better teacher-student relationship in the axes of satisfaction and instrumental help than the not-willing-to-connect group. Therefore, from the students' perspective, Facebook-mediated communication might serve as yet another platform to support their relationships with teachers with whom they already have good relationships. This is in line with our previous, qualitative study, which showed that real-time relationships are mirrored on Facebook (Hershkovitz \& Forkosh-Baruch, 2013), and in line with other studies about online/offline relationships (Callaghan \& Bower, 2012; Ivcevic \& Ambady, 2013; Sheldon, 2008). Therefore, SNS-mediated communication can support student-teacher relationships and, following on from that, might eventually contribute to the student's general well-being (cf. Pianta, 1999; Wentzel, 1998). Interestingly, these differences in student-teacher relationships between the willing-to-connect and the not-willing-to-connect groups were not observed in the teacher population. A possible explanation is that adolescents might feel the need for teachers to continually take part in their out-of-school life, while teachers do not necessarily feel so with regards to their students, as secondary school teachers might tend to keep emotions as intrusion in the classroom (cf. Hargreaves, 2000). This issue should be further studied in a future research.

Our findings also support previous studies indicating the critical role of teachers' educational beliefs in their technology integration practices, specifically Web 2.0-based platforms (Ertmer, 2005; Ertmer, Ottenbreit-Leftwich, Sadik, Sendurur, \& Sendurur, 2012; Sang, Valcke, van Braak, $\&$ Tondeur, 2010; Windschitl \& Sahl, 2002). These findings might have implications on the study of student-teacher relationships in general. Indeed, SNS are complex Web 2.0-based platforms requiring teachers and students to utilize both ICT skills and social skills. There is a clear need to supply teachers with elaborate technological skills for using SNS, as expected by their students. Assisting teachers with the needed IT skills for using SNS may therefore prove to be as important to their teaching agenda as supporting their instructional strategies. As Davis (2003) emphasized, 
knowledge of student-teacher relationships is often embedded within knowledge of a particular underlying approach (for example, motivation studies, being mostly interested in teachers as effective instructors, define "good" student-teacher relationships as those that support motivation and learning in classrooms). Our study suggests that online social media through which these relationships are facilitated (e.g., SNS) may also be a critical component of teacher-student relationships. Hence, the need for proficiency in using this media is crucial for teachers.

Due to their major role of SNS-mediated teacher-student relationship to students' academic and emotional development, as well as to teachers' professional development, the solution of banning SNS-based communication, already taken by some policymakers, is potentially damaging to the education system. Notwithstanding, it is also difficult to enforce, as technology has a path of its own, and communication needs create an impossible situation, which causes some teachers to break the rules and engage in SNS interaction with their students anyway. A banning policy affects the very teachers and students who most need this type of communication and could benefit from it. Moreover, a banning policy may send a message to teachers and students about the degree of trust and support of the system to its teachers. The alternative solution is promoting and supporting an effective use of SNS, as pursued with 21st century skills in general, which Ministries of Education worldwide implement and promote via national programs. As SNS-mediated communication is voluntarily facilitated, such a policy will not harm the teachers and students who do not wish to use it. Students, educators, parents, and policymakers should be well aware of the risks and challenges with which they are faced by using SNS. We argue that teacher-student relationships in the SNS-era may have a bearing on additional aspects of the school milieu, e.g., teaching and learning, achievements, and parents' involvement in schools. Therefore, we strongly recommend further research into these aspects, providing policymakers with insight on these issues, which will support evidence-based decisions, and possibly change existing policies.

\section{Conclusions}

In this quantitative study, we explored differences in personal characteristics, attitudes, and teacher-student relationships between students $(\mathrm{N}=587)$ and teachers $(\mathrm{N}=160)$ who are willing to connect to each other via social networking sites (referred to as willing-to-connect) and those who are not willing to do so (referred to as not-willing-to-connect). We did this via self-reported, online questionnaires. Summarizing the results, we have found the following:

1. Personal Characteristics

- Willing-to-connect teachers are younger, have less teaching experience and longer Facebook-usage experience than the not-willing-to-connect teachers.

- Willing-to-connect students are older and have more Facebook-friends than the not-willing-to-connect students. Furthermore, there are relatively more boys in the willing-to-connect group than in the not-willing-to-connect group.

2. Attitudes towards Using Facebook in Education

- Both willing-to-connect teachers and students tend to believe that Facebook can be used for teaching/learning and that it should not be banned for teacher-student communication in much higher rates than their not-willing-to-connect peers.

3. Perceptions of Teacher-Student Relationships

$\circ$ There were no significant differences in perceptions of teacher-student relationships between the willing-to-connect and the not-willing-to-connect teacher groups.

- Perceptions of satisfaction and instrumental help regarding students' relationships with their teachers were higher for the willing-to-connect students compared to their not-willing-to-connect peers. 
As with any study, this one is not without limitation. First of all, the way the research population was recruited, based on viral distribution of the research questionnaire, does not mean it is in any way representative of the whole Israeli teacher/student population. Furthermore, the fact that the participants were practically self-recruited (i.e., any person who was exposed to our viral distribution of the online questionnaire could have chosen not to take part in the research), and the fact that we used online questionnaires, might somehow bias the results.

The complex issue of teacher-student relationships in the SNS-era should be further studied. In particular, we urge further study of the implications of this phenomenon on additional aspects of the school milieu, including teaching and learning, achievements and parents' involvement in schools. This will allow broadening the body of knowledge regarding teacher-student relationships at large and will assist policymakers in taking evidence-based decisions.

\section{References}

Abbott, L. (2005). The nature of authentic professional development during curriculum-based telecomputing. Journal of Research on Technology in Education 37, 379-398.

Amichai-Hamburger, Y., \& Vinitzky, G. (2010). Social network use and personality. Computers in Human Behavior, 26, 1289-1295.

Ang, R. P. (2005). Development and validation of the teacher-student relationship inventory using exploratory and confirmatory factor analysis. The Journal of Experimental Education, 74, 55-73.

Ang, R. P., Chong, W. H., Huan, V. S., Quek, C. L., \& Yeo, L. S. (2008). Teacher-student relationship inventory: Testing for invariance across upper elementary and junior high samples. Journal of Psychoeducational Assessment, 26(4), 339-349.

Asterhan, C. S. C., \& Rosenberg, H. (2015). The promise, reality and dilemmas of secondary school teacher-student interactions in Facebook: The teacher perspective. Computers \& Education, 85, 134-148.

Barker, V. (2009). Older adolescents' motivations for social network site use: The influence of gender, group identity, and collective self-esteem. CyberPsychology \& Behavior, 12(2), 209-213.

Blonder, R., \& Rap, S. (in press). I like Facebook: Exploring Israeli high school chemistry teachers' TPACK and self-efficacy beliefs. Education and Information Technologies, doi 10.1007/s10639-0159384-6.

Boyd, D. M. (2008). Why youth social network sites: The role of networked publics in teenage social life. In D. Buckingham (Ed.), Youth, identity, and digital media (pp. 119-142). Cambridge, MA: The MIT Press.

Boyd, D. (2014). It's complicated: The social lives of networked teens. New Haven, CT: Yael University Press.

Boyd, D. M., \& Ellison, N. B. (2007). Social network sites: Definition, history, and scholarship. Journal of Computer-Mediated Communication, 13(1), 210-230.

Brandtzæg, P. B., Heim, J., \& Kaare, B. (2010). Bridging and bonding in social network sitesInvestigating family-based capital. International Journal of Web Based Communities, 6, 231-253.

Callaghan, N., \& Bower, N. (2012). Learning through social networking sites - The critical role of the teacher. Educational Media International, 49(1), 1-17.

Davis, H. A. (2003). Conceptualizing the role and influence of student-teacher relationships on children's social and cognitive development. Educational Psychologist, 38(4), 207-234.

Durrant, A., Frohlich, D., Sellen, A., \& Uzzell, D. (2011). The secret life of teens: Online versus offline photographic displays at home. Visual Studies, 26(2), 113-124. 
Ellison, N. B., \& Boyd, D. (2013). Sociality through social network sites. In Dutton, W. (Ed.), The Oxford handbook of internet studies (pp. 151-172). UK: Oxford University Press.

Elmore, R. F. (1996). Getting to scale with good educational practice. Harvard Educational Review, 66(1), $1-26$.

Ertmer, P. A. (2005). Teacher pedagogical beliefs: The final frontier in our quest for technology integration? Educational Technology Research and Development, 53(4), 25-39.

Ertmer, P. A., Ottenbreit-Leftwichb, A. T., Sadikb, O., Sendururc, E., \& Sendurur, P. (2012). Teacher beliefs and technology integration practices: A critical relationship. Computers \& Education, 59(2), 423435 .

Forkosh-Baruch, A. \& Hershkovitz, A. (2014). Teacher-student relationship in the Facebook-era. In P. Isaías, P. Kommers, T. Issa (Eds.), The evolution of the internet in the business sector: Web 1.0 to Web 3.0 (pp. 145-172). Hershey, PA: IGI Global.

Greenhow, C. (2011). Online social networks and learning. On the Horizon, 19(1), 4-12.

Halverson, A. (2014). Facebook usage in Thailand: The plurilingual competencies of Thai high school students and teachers (Unpublished doctoral dissertation). University of Illinois at Urbana-Champaign, Urbana, IL.

Hargreaves, A. (2000). Mixed emotions: Teachers' perceptions of their interactions with students. Teaching and Teacher Education, 16(8), 811-826.

Hershkovitz, A., \& Forkosh-Baruch, A. (2013). Student-teacher relationship in the Facebook-era: The student perspective. International Journal of Continuing Engineering Education and Life-Long Learning, 23(1), 33-52.

Hew, K. F. (2011). Students' and teachers' use of Facebook. Computers in Education, 27(2), 662-676.

Ivcevic, Z., \& Ambady, N. (2013). Face to (face)book: The two faces of social behavior? Journal of Personality, 81(3), 290-301.

Jaimeson, D. W., \& Thomas, K. W. (1974). Power and conflict in the student-teacher relationship. Journal of Applied Behavioral Science, 10(3), 321-336.

Koles, B., \& Nagy, P. (2012). Facebook usage patterns and school attitudes. Multicultural Education \& Technology Journal, 6(1), 4-17.

Lambert, L. G. (2007). Lasting leadership: Toward sustainable school improvement. Journal of Educational Change, 8, 311-322.

Lenhart, A., Madden, M., Macgill, A. R., \& Smith, A. (2007). Teens and social media. Pew Internet and American Life Project. Retrieved August 2012 from http://www.pewinternet.org/Reports/2007/Teensand-Social-Media.aspx

Livingstone, S. (2008). Taking risky opportunities in youthful content creation: Teenagers' use of social networking sites for intimacy, privacy and self-expression. New Media \& Society, 10(3), 393-411.

Livingstone, S., \& Brake, D. R. (2009). On the rapid rise of social networking sites: New findings and policy implications. Children \& Society, 24, 75-83.

Lowenthal, P. R. (2009). Social presence. In P. Rogers, G. Berg, J. Boettcher, C. Howard, L. Justice, \& K. Schenk (Eds.), Encyclopedia of distance and online learning (2nd ed.) (pp. 1900-1906). Hershey, PA: IGI Global.

MacFarlane, A. G. J. (2001). Information, knowledge and technology. In H. J. van der Molen (Ed.), Virtual university? Educational environments of the future (pp. 41-49). London: Portland Press.

Marwick, A. E., \& Boyd, D. (2010). I tweet honestly, I tweet passionately: Twitter users, context collapse, and the imagined audience. New Media and Society, 13, 96-113. 
Mazman, S. G., \& Usluel, Y. K. (2010). Modeling educational usage of Facebook. Computers \& Education, 55(2), 444-453.

Mazer, J. P., Murphy, R. E., \& Simonds, C. J. (2009). The effects of teacher self-disclosure via Facebook on teacher credibility. Learning, Media and Technology, 34(2), 175-183.

Mioduser, D., Nachmias, R., \& Forkosh-Baruch, A. (2008). New literacies for the knowledge society. In J. Knezek \& J. Voogt (Eds.), International handbook of information technology in education (pp. 23-42). New York, NY: Springer.

Pianta, R. C. (1999). Enhancing relationships between children and teachers. Washington, DC: American Psychological Association.

Quaglia, R., Gastaldi, F. G. M., Prino, L. E., Pasta, T., \& Longobardi, C. (2013). The pupil-teacher relationship and gender differences in primary school. The Open Psychology Journal, 6, 69-75.

Ranieri, M., Manca, S., \& Fini, A. (2012). Why (and how) do teachers engage in social networks? An exploratory study of professional use of Facebook and its implications for lifelong learning. British Journal of Educational Technology, 43(5), 754-769.

Rodgers, C. R., \& Raider-Roth, M. B. (2006). Presence in teaching. Teachers and Teaching: Theory and practice, 12, 265-287.

Saft, E. W. \& Pianta, R. C. (2001). Teachers' perceptions of their relationships with students: Effects of child age, gender, and ethnicity of teachers and children. School Psychology Quarterly, 16(2), 125 141.

Sang, G., Valcke, M., van Braak, J., \& Tondeur, J. (2010). Student teachers' thinking processes and ICT integration: Predictors of prospective teaching behaviors with educational technology. Computers \& Education, 54(1), 103-112.

Scardamalia, M., \& Bereiter, C. (2006). Knowledge building: Theory, pedagogy, and technology. In K. Sawyer (Ed.), Cambridge handbook of the learning sciences (pp. 97-118). New York: Cambridge University Press.

Sheldon, P. (2008). The relationship between unwillingness-to-communicate and students' Facebook use. Journal of Media Psychology, 20(2), 67-75.

Split, J. L., Koomen, H. M. Y., \& Jak, S. (2012). Are boys better off with male and girls with female teachers? A multilevel investigation of measurement invariance and gender match in teacher-student relationship quality. Journal of School Psychology, 50(3), 363-378.

Steinfield, C., Ellison, N. B., \& Lampe, C. (2008). Social capital, self-esteem, and use of online social network sites: A longitudinal analysis. Journal of Applied Developmental Psychology, 29(6), 434-445.

Subrahmanyam, K., Reich, S. M., Waechter, N., \& Espinoza, G. (2008). Online and offline social networks: Use of social networking sites by emerging adults. Journal of Applied Developmental Psychology, 29(6), 420-433.

Van House, N. (2007). Flickr and public image-sharing: Distant closeness and photo exhibition. In Proceedings of CHI 2007 (pp. 2717-2722). New York, NY: ACM Press.

Veletsianos, G., Kimmons, R., \& French, K. D. (2013). Instructor experiences with a social networking site in a higher education setting: Expectations, frustrations, appropriation, and compartmentalization. Educational Technology Research and Development, 61(2), 255-278.

Vie, S. (2008). Digital Divide 2.0: "Generation M" and online social networking sites in the composition classroom. Computers and Composition, 25(1), 9-23.

Wentzel, K. R. (1998). Social relationships and motivation in middle school: The role of parents, teachers, and peers. Journal of Educational Psychology, 90(2), 202-209. 
Windschitl, M., \& Sahl, K. (2002). Tracing teachers' use of technology in a laptop computer school: The interplay of teacher beliefs, social dynamics, and institutional culture. American Educational Research Journal, 39(1), 165-205.

Wong, A. F. L., Quck, C. L., Divaharan, S., Liu, W. C., Peer, J., \& Williams, M. D. (2006). Singapore students' and teachers' perceptions of computer-supported project work classroom learning environments. Journal of Research on Technology in Education, 38(4), 449-479.

Yeo, L. S., Ang, R. P., Chong, W. H., Huan, V. S., \& Quek, C. L. (2008). Teacher efficacy in the context of teaching low achieving students. Current Psychology, 27(3), 192-204.

\section{Appendix A: Teacher-Class Relationship Inventory (TCRI)}

\begin{tabular}{|c|c|c|}
\hline Item & Original Item (TSRI) & Adapted Item \\
\hline 1 & I enjoy having this student in my class & I enjoy teaching this class \\
\hline 2 & $\begin{array}{l}\text { If the student has a problem at home, } \\
\text { he/she is likely to ask for my help }\end{array}$ & $\begin{array}{l}\text { If students from this class have a prob- } \\
\text { lem at home, they are likely to ask for } \\
\text { my help }\end{array}$ \\
\hline 3 & $\begin{array}{l}\text { I would describe my relationship with } \\
\text { the student as positive }\end{array}$ & $\begin{array}{l}\text { I would describe my overall relation- } \\
\text { ship with this class as generally positive }\end{array}$ \\
\hline 4 & $\begin{array}{l}\text { This student frustrates me more than } \\
\text { most other students in my class }\end{array}$ & $\begin{array}{l}\text { This class frustrates me more than most } \\
\text { other classes I teach }\end{array}$ \\
\hline 5 & $\begin{array}{l}\text { If this student is absent, I will miss } \\
\mathrm{him} / \mathrm{her}\end{array}$ & $\begin{array}{l}\text { If I miss a lesson with this class, I will } \\
\text { miss them }\end{array}$ \\
\hline 6 & $\begin{array}{l}\text { The student shares with me things } \\
\text { about his/her personal life }\end{array}$ & $\begin{array}{l}\text { Students from this class share with me } \\
\text { things about their personal life }\end{array}$ \\
\hline 7 & $\begin{array}{l}\text { I cannot wait for this year to be over so } \\
\text { that I will not need to teach this stu- } \\
\text { dent next year }\end{array}$ & $\begin{array}{l}\text { I cannot wait for this year to be over so } \\
\text { that I will not need to teach this class } \\
\text { anymore }\end{array}$ \\
\hline 8 & If this student is absent, I feel relieved & $\begin{array}{l}\text { If I miss a lesson with this class, I feel } \\
\text { relieved }\end{array}$ \\
\hline 9 & $\begin{array}{l}\text { If this student needs help, he/she is } \\
\text { likely to ask me for help }\end{array}$ & $\begin{array}{l}\text { If students from this class need help, } \\
\text { they are likely to ask me for help }\end{array}$ \\
\hline 10 & $\begin{array}{l}\text { The student turns to me for a listening } \\
\text { ear or for sympathy }\end{array}$ & $\begin{array}{l}\text { Students in this class turn to me for a } \\
\text { listening ear or for sympathy }\end{array}$ \\
\hline 11 & $\begin{array}{l}\text { If this student is not in my class, I will } \\
\text { be able to enjoy my class more }\end{array}$ & $\begin{array}{l}\text { If I don't teach this class, I will be able } \\
\text { to enjoy my teaching more }\end{array}$ \\
\hline 12 & $\begin{array}{l}\text { The student depends on me for advice } \\
\text { or help }\end{array}$ & $\begin{array}{l}\text { This class depends on me for advice or } \\
\text { help }\end{array}$ \\
\hline 13 & $\begin{array}{l}\text { I am happy with my relationship with } \\
\text { this student }\end{array}$ & $\begin{array}{l}\text { I am happy with my relationship with } \\
\text { this class }\end{array}$ \\
\hline 14 & I like this student & I like this class \\
\hline
\end{tabular}




\section{Appendix B: Teacher-Student Relationship Inventory, responded by Students (TSRI-S)}

\begin{tabular}{|c|c|c|}
\hline Item & Original Item (TSRI) & Adapted Item \\
\hline 1 & I enjoy having this student in my class & $\begin{array}{l}\text { I think this teacher is enjoying having } \\
\text { me in his/her class }\end{array}$ \\
\hline 2 & $\begin{array}{l}\text { If the student has a problem at home, } \\
\text { he/she is likely to ask for my help }\end{array}$ & $\begin{array}{l}\text { If I encountered a problem at home, I } \\
\text { would likely approach this teacher for } \\
\text { help }\end{array}$ \\
\hline 3 & $\begin{array}{l}\text { I would describe my relationship with } \\
\text { the student as positive }\end{array}$ & $\begin{array}{l}\text { I would describe my relationship with } \\
\text { this teacher as positive }\end{array}$ \\
\hline 4 & $\begin{array}{l}\text { This student frustrates me more than } \\
\text { most other students in my class }\end{array}$ & $\begin{array}{l}\text { I think this teacher is frustrated by me } \\
\text { more than by most other students in } \\
\text { class }\end{array}$ \\
\hline 5 & $\begin{array}{l}\text { If this student is absent, I will miss } \\
\mathrm{him} / \mathrm{her}\end{array}$ & $\begin{array}{l}\text { I think my teacher would miss me if } \\
\text { I'm absent from class }\end{array}$ \\
\hline 6 & $\begin{array}{l}\text { The student shares with me things about } \\
\text { his/her personal life }\end{array}$ & $\begin{array}{l}\text { I share things about my personal life } \\
\text { with this teacher }\end{array}$ \\
\hline 7 & $\begin{array}{l}\text { I cannot wait for this year to be over so } \\
\text { that I will not need to teach this student } \\
\text { next year }\end{array}$ & $\begin{array}{l}\text { I think this teacher cannot wait for the } \\
\text { moment he/she does not need to have } \\
\text { me in his/her class any more }\end{array}$ \\
\hline 8 & If this student is absent, I feel relieved & $\begin{array}{l}\text { I think this teacher would feel relieved } \\
\text { if I weren't in his class }\end{array}$ \\
\hline 9 & $\begin{array}{l}\text { If this student needs help, he/she is like- } \\
\text { ly to ask me for help }\end{array}$ & $\begin{array}{l}\text { If I need help, I am likely to ask this } \\
\text { teacher for help }\end{array}$ \\
\hline 10 & $\begin{array}{l}\text { The student turns to me for a listening } \\
\text { ear or for sympathy }\end{array}$ & $\begin{array}{l}\text { I turn to this teacher for a listening ear } \\
\text { or for sympathy }\end{array}$ \\
\hline 11 & $\begin{array}{l}\text { If this student is not in my class, I will } \\
\text { be able to enjoy my class more }\end{array}$ & $\begin{array}{l}\text { I think this teacher will enjoy the class } \\
\text { more if I am not in it }\end{array}$ \\
\hline 12 & $\begin{array}{l}\text { The student depends on me for advice or } \\
\text { help }\end{array}$ & $\begin{array}{l}\text { I depend on this teacher for advice or } \\
\text { help }\end{array}$ \\
\hline 13 & $\begin{array}{l}\text { I am happy with my relationship with } \\
\text { this student }\end{array}$ & $\begin{array}{l}\text { I am happy with my relationship with } \\
\text { this teacher }\end{array}$ \\
\hline 14 & I like this student & I like this teacher \\
\hline
\end{tabular}




\section{Biographies}

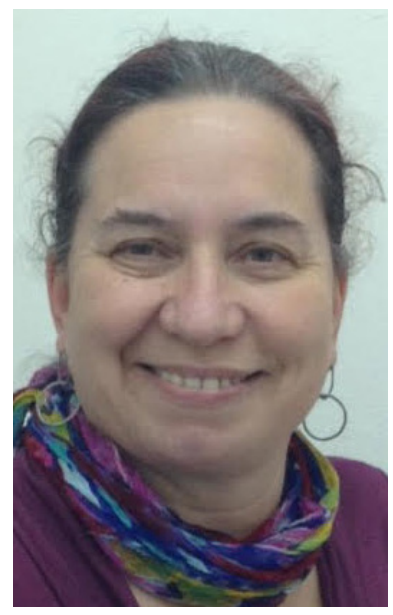

Alona Forkosh-Baruch is a senior lecturer at the Graduate school at Levinsky College of Education and a researcher at the Science and Technology Education Center in the School of Education, Tel Aviv University (Israel). She holds a Ph.D. in Science Education, an M.A. in Technologies in Education, and a B.A in Psychology and in Education. Her research interest intersects several aspects of Information and Communication Technologies in education, from teachers', students', pre-service teachers' and teacher educators' point of view. Among her fields of research are mobile technology in education and teacher education, social media in education and education in the social media era, teacher professional development, and systemic implementation of technology in education.

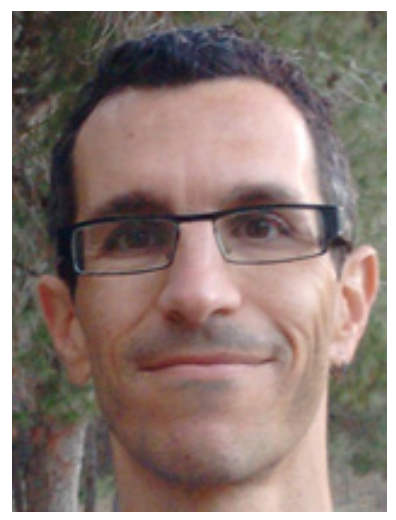

Arnon Hershkovitz is a Senior Lecturer at the Department of Mathematics, Science and Technology Education, in the School of Education, Tel Aviv University (Israel). He holds a Ph.D. in Science Education, an M.A. in Applied Mathematics, and a B.A. in Mathematics and Computer Science. His research interests lie at the intersection of education and technology, using various methodologies, including educational data mining and learning analytics. Among his research interests are one-to-one computing in the classroom, learning/teaching processes in the social media era, student-teacher relationship, and genealogy as a unique lifelong learning experience in the information age.

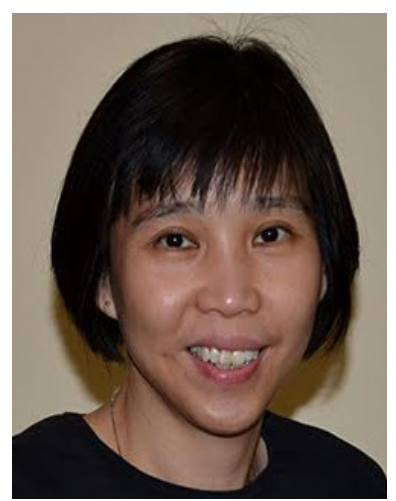

Rebecca Ang is Associate Professor of Psychological Studies Academic Group, National Institute of Education, Nanyang Technological University, Singapore. She obtained her PhD in School Psychology (specializing in clinical child psychology) from Texas A\&M University. She is a Nationally Certified School Psychologist in the USA and a Registered Psychologist in Singapore. Her research and professional interests include developmental child psychopathology and, in particular antisocial and aggressive behavior, and related prevention and intervention work. She is also interested in parent-child relationships, teacher-student relationships, and the impact of the quality of such relationships on child, familial and school adjustment/functioning. 